\title{
The Development of Community-Based Health Center Services in Banyuwangi
}

\author{
Jayanti Dian Eka Sari ${ }^{1}$, Diansanto Prayoga ${ }^{2}$ \\ ${ }^{1,2}$ Public Health Study Program of Airlangga University-PDD Banyuwangi, Indonesia \\ jayantidian. unair@gmail.com \\ diansantoprayogadf $\mathrm{km}$. unair.ac.id
}

\begin{abstract}
The purpose of this research is to analyze the health center services, analyze the potential benefits of health centers, making recommendations based service development and potential community health centers. This research uses descriptive analytic method with cross sectional approach. The results showed all PHC has health Individual Attempt and Essential Public Health Attempt and Development, but the amount of power that are not held in accordance with the standards Permenkes No. 75 2014. PHC is classified based on the potential of the area (tourism (16\%), industry $(11 \%)$, agriculture $(64 \%)$ and estate $(9 \%)$ ), geographical conditions indicate that Banyuwangi also has the potential for catastrophic volcanic eruptions, landslides, earthquakes, tsunamis and floods, so that these conditions also need to be considered in drafting development. The draft recommendation development services be adapted to the potential of each health center by involving the active participation of society through empowerment activities. The conclusion of this study is featured PHC services classification based on potential and active role of local communities to encourage local authorities to set up an innovative program for the development of healthcenter services that support the planning of activities and budget of the area become more effective and efficient according to the conditions and problems of each region.
\end{abstract}

Keywords - Development, potential, public health center, empowerment, services

\section{INTRODUCTION}

The district government Banyuwangi committed to make the health sector as one of the programs development priorities. In 2013, the Health Service Banyuwangi district has an action plan related to the increase in the health sector, namely equality of access and quality of health services, improvement of maternal and child health, as well as empowering people to live independent and healthy [4]. Three things are prioritized with success indicators include people unable to reach health facilities services and quality, decrease morbidity and mortality of mothers and children, and communities are able to live in a healthy environment with a healthy way of life behavior. Therefore, the Regional Government of Banyuwangi has provided 45 health centers in 24 Districts to provide services for the entire community Banyuwangi.
Some programs will be done in terms of equality of access and quality of health services, including program Jamkesmin (Poor Health Insurance), ISO certification in 6 health centers, improvement of public health services Based Family Physicians, the implementation of e-health in the hospital, the utilization of a home for the family patients in the hospital, Simpuswangi increase in health centers, and preparations for establishing a free hospital (RS classless).The program will be done in improving maternal and child health, including programs Mother Child Health Society Movement Mandiri (Gema Insani), supplementary feeding (PMT) for children malnutrition, stunting and maternal chronic energy malnutrition (Bumil KEK).While the community empowerment program for independent and healthy living include increased efforts PHBS (Clean and Healthy Behaviors) through a schoolbased campaign, villages ODF (Open Defecation Free), and the campaign against HIV / AIDS by involving the boarding school.

Banyuwangi District Government also continued to boost the quality of service through the completeness of each Public Health Center (PHC) facilities in Banyuwangi. Complete facilities, medical personnel credible and easy access to the place of service is expected to improve the quality of public health degree Banyuwangi.Efforts for quality improvement towards a continued effort by the Government of Banyuwangi district. Excavation potential in each area and health centers of excellence to be something that needs to be studied, so that the health center as a leading service unit (first level) can provide excellent service to the community.Through potentials / advantages of each health center can support planning activities and budgets become more effective and efficient. 


\section{METHODS}

This research is descriptive and analytical. The data used is secondary data. Secondary data were obtained through the study of documents. Data analysis was done using descriptive analysis.

\section{RESULTS}

\section{A. Health Services}

The process component in a system is a collection of elements contained in the system and serves to transform inputs into outputs planned.In the context of fulfilling health services based on the needs and conditions of the community, according to Permenkes no 75 of 2014 PHC can be described as based on the location characteristics and the ability of work [9]. Based on regent decree Banyuwangi no. $188 / 54 / \mathrm{KEP} / 429.011 / 2016$ on the determination service status public health centers in district Banyuwangi , PHC in the district banyuwangi based on the ability of consisting of 18 puskesmas non in patient care and 27 patient health centers [2]. Puskesmas hold public health efforts in the first degree and individual health efforts first instance .Public health efforts the first covering public health efforts essential and development.

Essential public health efforts include: health promotion services, environmental health services, maternal health care, child and family planning, nutrition services and disease prevention and control services.In order to achieve minimum service standards for districts / cities in the field of health, each health center should organize essential public health efforts.All PHC in the district Banyuwangi have public health efforts essential, however if it is associated with components energy purposes will have not meet standart energy purposes will this may affect the scope of the minimum service standart the health sector in Banyuwangi district.

The number of personnel health workers who more limited with the workloads many often make the health workers takes some responsibility to give priority to health services in the community. Look at the level of the energy purposes will limited if the duties and responsibilities in puskesmas adapted to educational background concerned. Such as paramedics who back positioned with a medical on the not on planning positions (manager) and or administration, that performance by can optimized.
In addition, need to the presence of programs that innovative to support PHC in applying prime services and optimal. One of the programs innovative things can be done by namely by citizens participation to participate seek degrees public health highest. The first level of an individual's health efforts carried out in the form of outpatient, emergency service, service one day, home care and inpatient or based on consideration of the needs of the health services. In the planning of individual health efforts required the identification of resources and characteristics of the area so that the allocation and preparedness efforts of individual health services effectively and efficiently to address health problems in the region of their respective health centers.

Currently there are many programs that are easing the burden on society, but the program is still moving on curative and rehabilitative health services from health centers, while programs directed to promotion and prevention still received less attention from various parties. The paradigm of "health" has not been understood by various parties, most of them are still oriented to the paradigm of "sick".In this case the active participation of the community is needed in improving public health.Mindset to nourish those who "originated from them and for them" should begin implanted and carried out. It is intended for Banyuwangi people become stronger, ready, alert and independent in the face of a variety of health problems in their environment.In addition, with the effort to involve the active participation of society to be more careful, more care and more cooperative more with the surrounding environment tempt residence, then a little more duties and responsibilities of health workers to be reduced because of the importance of improving the health status of the community is not only a concern of health workers alone but also the local community.

\section{B. Potential Health Benefits Based On Topographic Regions And Characteristics Of Society}

Potential Banyuwangi in supporting the existence of health centers in the working area is determined by several factors. PHC is a leading health care functional unit as the technical implementation of district health offices or cities that implement 
educational efforts, prevention and treatment of disease cases in the region work in an integrated and coordinated.

Potential available in each health center has a difference. The potential difference is based on area, population, geographical location, livelihoods and tourism areas. This potential will have consequences in the development of health centers. That potential will be optimized if it is seen as an opportunity for local Banyuwangi governments to develop health centers. Based zoning area, boundaries by Banyuwangi district, area beaches and mountains can be seen in Figure 1.

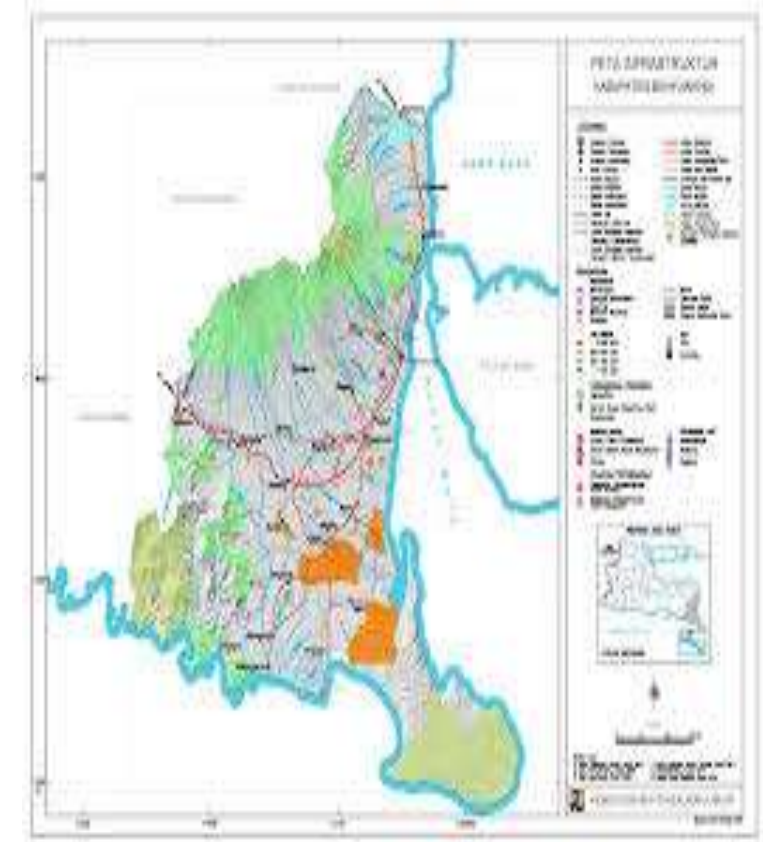

Fig 1. Map of the Administrative District. Banyuwangi (Source: Kab. Banyuwangi 2011-2013) [2]

The district banyuwangi consisting of the mountainous region, the sea, plantation, agriculture and industry make local authorities to feel the need to increase the health service any potential areas .This is necessary because of different characteristics the will be affected the characteristic of health problems faced in each area, so that health services superior prepared is different in accordance with of the characteristics of and the local community.

See areas Banyuwangi rich in the natural resources, so it cannot be denied too if Banyuwangi is also a areas prone to will disaster as a mountain erupted, tsunami, an earthquake, landslide and flood .The potential for disaster the working areas of puskesmas also need to be attention .

Besides, the positive side of location district banyuwangi officially is the potential that should become attention also .Picture the following is a map of tourism potential in district banyuwangi figure 2 .

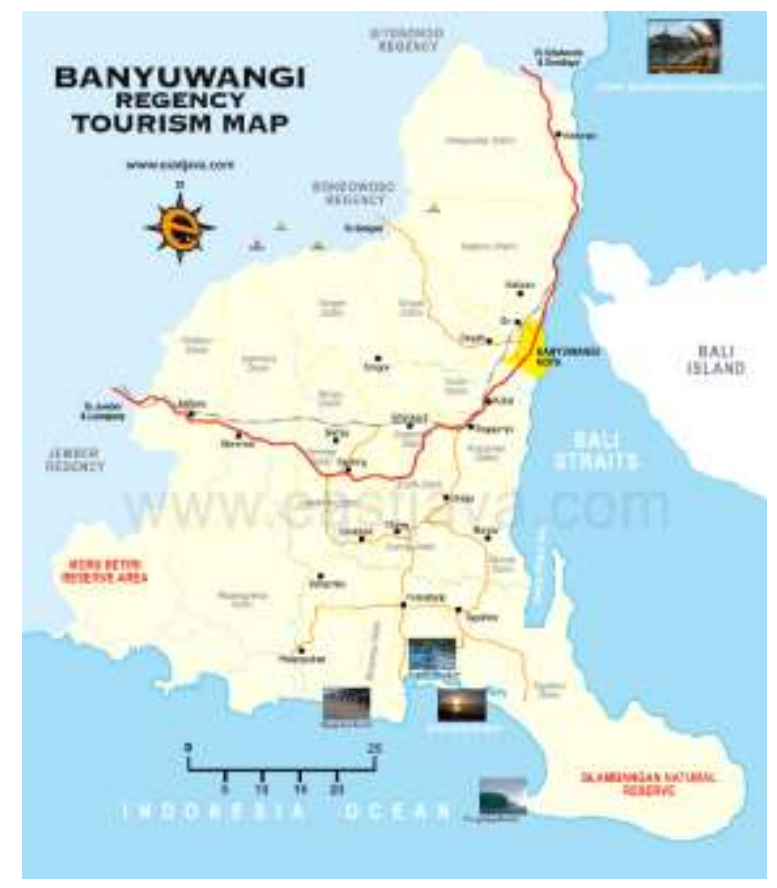

Fig 2. Maps of Banyuwangi Regency Tourism(source: BAPEDA of District Banyuwangi)[2]

Greater potential natural tourism in Banyuwangi district of course will attract many travelers to visit banyuwangi, good tourists domestic and foreign tourists. The increasing number of tourists who come to banyuwangi only do not only provide input economically in the community and regional government, but also to donate cases of.For that required an active role the community and health workers especially for those who live in the areas surrounding the tourism potential to be more careful and sensitive again of the changes that happens in his territory.Completeness health facilities according to potential of course to be supported to make the services given can more optimal and prima. A kind of facilities and services seed of course differ across $\mathrm{PHC}$ hanging from category do the PHC .

\section{Recommendations Development Based Health Services Potential And Society}

The following are recommended development seed services puskesmas in the district Banyuwangi. 
TABLE I

RECOMMENDATIONS SEED SERVICE PUSKESMAS IN THE DISTRICT BANYUWANGI.

\begin{tabular}{|c|c|c|c|}
\hline Puskesmas & $\begin{array}{c}\text { The status of } \\
\text { service }\end{array}$ & Type & $\begin{array}{c}\text { Types of } \\
\text { services seed }\end{array}$ \\
\hline Sumberagung & Outpatient & $\begin{array}{l}\mathrm{PHC} \\
\text { rural }\end{array}$ & tourism \\
\hline Siliragung & $\begin{array}{l}\text { Rawat jalan } \\
\text { dan Rawat } \\
\text { inap }\end{array}$ & $\begin{array}{l}\text { PHC } \\
\text { rural }\end{array}$ & tourism \\
\hline Grajagan & Outpatient & $\begin{array}{l}\mathrm{PHC} \\
\text { rural }\end{array}$ & tourism \\
\hline Kedungwungu & Outpatient & $\begin{array}{l}\text { PHC } \\
\text { rural }\end{array}$ & $\begin{array}{c}\text { environmental } \\
\text { health }\end{array}$ \\
\hline Tembokrejo & Outpatient & $\begin{array}{l}\mathrm{PHC} \\
\text { rural }\end{array}$ & UGD \\
\hline Tapanrejo & Outpatient & $\begin{array}{l}\mathrm{PHC} \\
\text { rural }\end{array}$ & UGD \\
\hline Tenpo & Outpatient & $\begin{array}{l}\text { PHC } \\
\text { rural }\end{array}$ & UGD \\
\hline Jajag & Outpatient & $\begin{array}{l}\text { PHC } \\
\text { urban }\end{array}$ & Home Care \\
\hline Yosomulyo & Outpatient & $\begin{array}{l}\text { PHC } \\
\text { rural }\end{array}$ & UGD \\
\hline Tulungrejo & Outpatient & $\begin{array}{l}\text { PHC } \\
\text { urban }\end{array}$ & Home Care \\
\hline Genteng kulon & Outpatient & $\begin{array}{l}\text { PHC } \\
\text { urban }\end{array}$ & Home Care \\
\hline Kebaman & Outpatient & $\begin{array}{l}\text { PHC } \\
\text { rural }\end{array}$ & UGD \\
\hline Parijatah Kulon & Outpatient & $\begin{array}{l}\text { PHC } \\
\text { rural }\end{array}$ & UGD \\
\hline Wonosobo & Outpatient & $\begin{array}{l}\text { PHC } \\
\text { rural }\end{array}$ & UGD \\
\hline Gladag & Outpatient & $\begin{array}{l}\text { PHC } \\
\text { rural }\end{array}$ & UGD \\
\hline Kabat & Outpatient & $\begin{array}{l}\text { PHC } \\
\text { urban }\end{array}$ & Home Care \\
\hline Badean & Outpatient & $\begin{array}{l}\text { PHC } \\
\text { rural } \\
\end{array}$ & UGD \\
\hline Karangsari & Outpatient & $\begin{array}{l}\text { PHC } \\
\text { rural }\end{array}$ & UGD \\
\hline Kembiritan & Outpatient & $\begin{array}{l}\text { PHC } \\
\text { urban }\end{array}$ & Home Care \\
\hline Gendoh & Outpatient & $\begin{array}{l}\text { PHC } \\
\text { rural }\end{array}$ & PONED \\
\hline Songgon & Outpatient & $\begin{array}{l}\text { PHC } \\
\text { rural }\end{array}$ & PONED \\
\hline Paspan & Outpatient & $\begin{array}{l}\text { PHC } \\
\text { rural }\end{array}$ & UGD \\
\hline Sobo & Outpatient & $\begin{array}{l}\text { PHC } \\
\text { urban }\end{array}$ & $\begin{array}{l}\text { Tourism and } \\
\text { Home care }\end{array}$ \\
\hline Kertosari & Outpatient & $\begin{array}{l}\text { PHC } \\
\text { urban }\end{array}$ & $\begin{array}{c}\text { Tourism and } \\
\text { Home care }\end{array}$ \\
\hline Singotrunan & Outpatient & $\begin{array}{l}\text { PHC } \\
\text { urban }\end{array}$ & Home Care \\
\hline Mojopanggung & Outpatient & $\begin{array}{l}\text { PHC } \\
\text { urban }\end{array}$ & Home Care \\
\hline Kelir & Outpatient & $\begin{array}{l}\mathrm{PHC} \\
\text { rural }\end{array}$ & UGD \\
\hline Klatak & Outpatient & $\begin{array}{l}\text { PHC } \\
\text { urban }\end{array}$ & Tourism and K3 \\
\hline
\end{tabular}

\begin{tabular}{|c|c|c|c|}
\hline Gitik & $\begin{array}{c}\text { For inpatient } \\
\text { or outpatient } \\
\text { treatment }\end{array}$ & $\begin{array}{l}\text { PHC } \\
\text { urban }\end{array}$ & UGD \\
\hline Wongsorejo & $\begin{array}{c}\text { For inpatient } \\
\text { or outpatient } \\
\text { treatment }\end{array}$ & $\begin{array}{l}\text { PHC } \\
\text { rural }\end{array}$ & $\begin{array}{l}\text { Inpatient and } \\
\text { PONED }\end{array}$ \\
\hline Benculuk & $\begin{array}{c}\text { For inpatient } \\
\text { or outpatient } \\
\text { treatment }\end{array}$ & $\begin{array}{l}\text { PHC } \\
\text { urban }\end{array}$ & PONED \\
\hline Pesanggaran & $\begin{array}{c}\text { For inpatient } \\
\text { or outpatient } \\
\text { treatment }\end{array}$ & $\begin{array}{l}\mathrm{PHC} \\
\text { rural }\end{array}$ & PONED \\
\hline Purwoharjo & $\begin{array}{c}\text { For inpatient } \\
\text { or outpatient } \\
\text { treatment }\end{array}$ & $\begin{array}{l}\mathrm{PHC} \\
\text { rural }\end{array}$ & PONED \\
\hline Singojuruh & $\begin{array}{c}\text { For inpatient } \\
\text { or outpatient } \\
\text { treatment }\end{array}$ & $\begin{array}{l}\mathrm{PHC} \\
\text { rural }\end{array}$ & PONED \\
\hline Kedungrejo & $\begin{array}{c}\text { For inpatient } \\
\text { or outpatient } \\
\text { treatment }\end{array}$ & $\begin{array}{l}\text { PHC } \\
\text { urban }\end{array}$ & PONED \\
\hline Kalibaru kulon & $\begin{array}{c}\text { For inpatient } \\
\text { or outpatient } \\
\text { treatment }\end{array}$ & $\begin{array}{l}\text { PHC } \\
\text { rural }\end{array}$ & $\begin{array}{l}\text { PONED and } \\
\text { Tourism }\end{array}$ \\
\hline Sambirejo & $\begin{array}{c}\text { For inpatient } \\
\text { or outpatient } \\
\text { treatment }\end{array}$ & $\begin{array}{l}\text { PHC } \\
\text { rural }\end{array}$ & PONED \\
\hline Kebondalem & $\begin{array}{c}\text { For inpatient } \\
\text { or outpatient } \\
\text { treatment }\end{array}$ & $\begin{array}{l}\text { PHC } \\
\text { rural }\end{array}$ & PONED \\
\hline Sumberberas & $\begin{array}{c}\text { For inpatient } \\
\text { or outpatient } \\
\text { treatment }\end{array}$ & $\begin{array}{l}\text { PHC } \\
\text { urban }\end{array}$ & Inpatient dan K3 \\
\hline Sepanjang & $\begin{array}{c}\text { For inpatient } \\
\text { or outpatient } \\
\text { treatment }\end{array}$ & $\begin{array}{l}\text { PHC } \\
\text { rural }\end{array}$ & PONED \\
\hline Sempu & $\begin{array}{c}\text { For inpatient } \\
\text { or outpatient } \\
\text { treatment }\end{array}$ & $\begin{array}{l}\mathrm{PHC} \\
\text { rural }\end{array}$ & PONED \\
\hline Licin & $\begin{array}{c}\text { For inpatient } \\
\text { or outpatient } \\
\text { treatment }\end{array}$ & $\begin{array}{l}\text { PHC } \\
\text { rural }\end{array}$ & $\begin{array}{c}\text { Sanity and } \\
\text { tourism }\end{array}$ \\
\hline Bajulmati & $\begin{array}{c}\text { For inpatient } \\
\text { or outpatient } \\
\text { treatment }\end{array}$ & $\begin{array}{l}\text { PHC } \\
\text { rural }\end{array}$ & PONED \\
\hline Tegaldlimo & $\begin{array}{c}\text { For inpatient } \\
\text { or outpatient } \\
\text { treatment }\end{array}$ & $\begin{array}{l}\text { PHC } \\
\text { rural }\end{array}$ & Tourism \\
\hline Tegalsari & $\begin{array}{c}\text { For inpatient } \\
\text { or outpatient } \\
\text { treatment }\end{array}$ & $\begin{array}{l}\text { PHC } \\
\text { rural }\end{array}$ & PONED \\
\hline
\end{tabular}

\section{CONCLUSIONS}

All PHC in Banyuwangi district has had Effort Essential Public Health and Health Services Individual corresponding Decree No. 75 Year 2014 [9]. Each health center also has a Public Health Efforts different development priorities based on local health problems.to rewrite. 
1. Recommendations the development of PHC services based are categorized be potential health care tourneonatal obstetric care and essential basic (PONED), mental health , occupational health and safety (K3), of environmental health , home care and the emergency room .

2. Of the service puskesmas seed based potential and an active role well-off communities encourage local governments to prepared a program innovative for the development of puskesmas services that supports planning activities and budget regions has become more effective and efficient according to the conditions and problems each area .

\section{REFERENCES}

[1] Arikunto,S. Prosedur Penelitian Suatu Pendekatan Praktik. Jakarta: Rineka Cipta, 2010.

[2] Badan Pusat Statistik. Banyuwangi Dalam Angka Tahun 2015 (Banyuwangi in Figure). . Banyuwangi: BPS Kabupaten Banyuwangi. http://banyuwangikab.bps.go.id (AksesTanggal 20 Maret 2016).

[3] Convelo G. Cevilla, etc. Pengantar Metode Penelitian. Jakarta: Universitas Indonesia. 1993.

[4] Dinas Kesehatan Kabupaten Banyuwangi, Profil Kesehatan Kabupaten Banyuwangi Tahun 2014. Banyuwangi: Dinas Kesehatan Kabupaten Banyuwangi. 2015.

[5] Hasibuan,S.P. Manajemen Sumber Daya Manusia. Edisi Revisi.Jakarta: PT.BumiAksara. 2007.

[6] Mardiasmo. Akuntansi Sektor Publik. Yogyakarta: Andi.. 2002.

[7] Mardalis. Metode Penelitian Suatu Pendekatan Proposal. Jakarta : Bumi Aksara. 1999.

[8] Mulyadi. Sistem Perencanaan dan Pengendalian Manajemen. Jakarta: Salemba Empat. 2009.

[9] Kementerian Kesehatan Republik Indonesia. Peraturan Menteri Kesehatan Nomor 75 Tahun 2014 Tentang Pusat Kesehatan Masyarakat. Jakarta: Kementerian Kesehatan Republik Indonesia. 2014

[10] Sudarto. Metodologi Penelitian Filsafat. Jakarta : Raja GrafindoPersada. 1995. 